\title{
Indirect costs and incidence of caregivers' short-term absenteeism in Poland, 2006- 2016
}

\author{
Błażej Łyszczarzi]
}

\begin{abstract}
Background: There is a growing interest in the costs of informal care; however, the results of previous studies mostly rely on self-reported data, which is subject to numerous biases. The aim of this study is to contribute to the topic by estimating the indirect costs of short-term absenteeism associated with informal caregiving in Poland with the use of social insurance data on care absence incidence.

Methods: The human capital method was used to estimate the indirect costs of caregiving from a societal perspective. The incidence of caregiving was identified based on the Social Insurance Institution's data on absence days attributable to care provided to children and other family members. Gross domestic product (GDP) per worker was used as a proxy of labour productivity. Deterministic one-way sensitivity analysis was performed.

Results: The indirect costs of short-term caregivers' absenteeism in Poland was $€ 306.2$ million (0.116\% of GDP) in 2006 and increased to $€ 824.0$ million in 2016 (0.180\% of GDP). The number of care absence days grew from 5.9 million ( 0.45 days per worker) in 2006 to 10.6 million ( 0.70 days per worker) in 2016. Approximately $85 \%$ of the total costs were attributable to child care. The results of the sensitivity analysis show that the indirect costs varied from the base scenario by -30.8 to $+15.8 \%$.

Conclusion: Informal short-term caregiving leads to substantial productivity losses in the Polish economy, and the dynamic upward trend of care absence incidence suggests that the costs of caregiving are expected to rise in the future.
\end{abstract}

Keywords: Caregiving, Indirect cost, Absenteeism, Cost-of-care, Economic losses, Poland

\section{Background}

Informal caregiving for those requiring care during sickness is a complex activity that has multidimensional consequences for both the care recipients and the carers. The former can benefit from personalized and more supportive care, resulting in improved well-being and health status $[1,2]$. On the other hand, caregivers face increased psychological and physical distress and, if left unsupported, may experience health deterioration [3] as well as other negative social and economic consequences, including financial strains and work disruptions $[4,5]$.

Health services research in the last two decades has witnessed a growing interest in the economic consequences

Correspondence: blazej@cm.umk.pl

Department of Public Health, Faculty of Health Sciences, Nicolaus Copernicus University in Toruń, ul. Sandomierska 16, 85-830 Bydgoszcz, Poland of caregiving, with a particular focus on the costs of informal care delivery [6-8]. These costs can be examined at an individual, household, and societal level, and recent taxonomy lists twelve caregiving cost categories grouped into three domains: employment consequences, out-ofpocket expenses, and caregiving labour [9]. Because non-institutionalized care provided by a family member or another related person is not a paid occupation, and because it is located outside of the formal economy [10], the costs of caregiving are not easy to capture [11]. The traditional approach to cost evaluation based on identifying financial flows (reimbursements, fees, remunerations) is of little use here, and this has resulted in the development of methods allowing for indirect valuation of informal care provision by attributing certain values based on opportunity cost, proxy good prices or contingent valuation, 
among others [12]. All of these methods have certain weaknesses, and their usefulness depends on the study context [13]. Regardless of the method used for care valuation, most of the studies on the cost of care rely on self-reported data [14]. This fact reflects the informal character of family caregiving, which is generally located beyond the scope of data collection for administrative purposes. With low accessibility to data on formal economic activity associated with family caregiving, researchers often need to rely on self-reported data, which is subject to numerous biases [15], and for this reason, caution is needed in drawing conclusions from studies based on surveys.

Numerous studies have reported on the cost of care provided informally, both in the context of particular diseases and - less often - for overall costs regardless of the condition requiring care. Of the 365 cost-of-illness studies reviewed in 2006, 75 papers estimated the cost of informal care [16]; 74 of these were disease-specific analyses, while only one study examined the cost of care for all diseases together. Despite this imbalance in the focus of cost-of-care research, several studies attempted to assess the aggregate societal cost of caregiving regardless of a disease category. A US study estimated the market value of care provided by unpaid family members and friends to ill and disabled adults at \$196 billion in 1997, the amount exceeding the costs of home health care and nursing home care combined [17]. A more recent American study estimated the cost of caregivers' short-term absenteeism in 2010 at $\$ 25.2$ billion [18] or $0.168 \%$ of the country's gross domestic product (GDP). Another study analysed the replacement cost of informal caregiving in Australia (2015 data), providing an estimated cost of $\$ 60.3$ billion, equivalent to $3.8 \%$ of GDP [19].

Most of the studies concerned with the cost of caregiving focus on long-term care provided to the elderly population, because this caring process generates the highest burden, in terms of both physical and emotional constraints and economic consequences [20-22]. Less is known about the caregiving process for children; in this case, most of the economic evidence is limited to the cost of specific conditions [23-25] and the overall incidence or determinants of all-cause absenteeism with no explicit reference to cost analysis [26, 27]. There is also little evidence regarding the cost of care provided occasionally, particularly by those who remain active in the labour market and deliver care while absent from work. It should be emphasized that such short-term informal care is addressed to diverse recipients, including sick children and adults suffering from conditions with relatively short recovery prospects or from long-term disabilities and chronic diseases. In the approach used in this study, the term 'short-term' applies to the period caregivers devote to providing care, not to the duration of care recipient's sickness.
Therefore, this study is concerned with the indirect costs (productivity losses) of short-term informal caregiving in Poland, and it attempts to contribute to the growing literature on the economic consequences of informal care by addressing some of the gaps and methodological issues mentioned above.

\section{Methods}

To assess the magnitude and costs of caregivers' short-term absenteeism, data from the Social Insurance Institution (SII), which provides care allowances for the working population in Poland, was used. Numbers of absence episodes and days associated with care provided to a relative reported by the SII were used to identify the amount of time lost from work due to caregiving. Care allowance in Poland is granted to a person who provides care for a child or other family member. The former category refers to children up to the age of 14 , while the latter category includes spouses, parents, a child's parent, stepparents, in-laws, grandparents, grandchildren, siblings and children aged $>14$. Hence, the category referring to care provided to 'others' also includes older children because the way the data are reported does not allow them to be separated from the total number. Consequently, 'child care' only accounts for children up to 14 years of age. The total duration of care allowance per household is limited to 60 days for child care and 14 days for care of others per year, regardless of the number of people for whom care is provided [28]. However, the insured caregiver is able to use more absence days in a year; in such a case the caregiver does not receive allowance and is not paid for the time of absence. The data on the number of absence days and episodes used here contains both paid and unpaid absences. Therefore, it reflects the total time of work lost because of caregiving even if the allowance is not paid. Any days of care that are provided during an employee's holiday are not reported in the data used here. Part-time employment is not accounted for in SII's data collection; this means that a workday lost because of a part-time worker absence was counted as a whole day. Thus, an adjustment for part-time employment was used as a part of the sensitivity analysis, and it was assumed that an average part-time employee works half-time ( $20 \mathrm{~h}$ weekly).

All the data on incidence and length of absence episodes were taken from SII's yearly reports on sickness absence in Poland [29]. As such, the analysis only accounts for short-term care episodes; however, it does not make any distinction with regard to the duration of sickness. Therefore, care for those suffering from long-term or chronic diseases is also included in the analysis, but only if the caregivers provide assistance on a short-term basis. 
The human capital method (HCM), which is the most common approach to indirect costs analyses [30], was used to estimate the productivity losses of caregiving from a societal perspective. Using the HCM means that all potential production not performed by caregivers because of relatives' morbidity was counted as lost productivity (indirect cost) $[16,31]$. The HCM was chosen because, in short-term absenteeism, it is unlikely that a person absent from work would be replaced by employing another worker; thus, an alternative method of friction cost does not seem to be an appropriate choice here. The productivity losses identified referred to all diseases combined, and no information on disease-specific absence was obtainable. Average gross domestic product (GDP) per worker was used to proxy labour productivity, and it was adjusted for decreasing marginal labour productivity. According to the law of diminishing marginal productivity, each additional worker produces a decreasing increment of output, and for this reason, the output increments that would have been gained in the absence of the caregiving would have been lower for each additional employee compared to the average productivity in the economy. To account for this fact, a 0.65 correction coefficient that reflects a relationship between marginal and average productivity and approximates the output elasticity of labour in the Cobb-Douglas production function in Europe [32] was applied. The costs were expressed in Euro $(€)$ currency using the average exchange rate from the period of 2006-2016, which is 4.07 zlotys per $€$.

Deterministic one-way sensitivity analysis was performed to test how variations in model parameters affect the cost estimates. The following parameter changes for the results for the year 2016 were used:

- extreme values of exchange rates from the whole period;

- \pm 0.05 changes in a coefficient adjusting for labour productivity (as suggested in recommendations for indirect cost estimation methods in Poland [33]); and

- an additional - 0.15 decrease in productivity of caregivers who potentially might be less efficient than workers on average ${ }^{1}$;

- gross value added instead of GDP as a measure of productivity;

- accounting for part-time employment; $6.2 \%$ of total employment in Poland in 2016 was part-time [36]; thus, it was assumed that this share of caregivers worked half-time.

The number of absence days was not subject to changes in the sensitivity analysis as it was based on exact numbers from insurance registries and not on estimates.

\section{Results}

Incidence of informal caregiving

The Social Insurance Institution (SII) reported 5944.6 thousand absence days related to care provided to a family member in 2006, and this number grew to $10,613.4$ thousand in 2016, a growth of 78.5\%. Most of these absence days ( $\sim 85 \%$ on average throughout the period) were associated with care provided to children aged up to 14 years. There was evident gender-related disparity in caregivers' absenteeism. The number of absence days for women was 3.1 times higher on average than that for men (7861.2 thousand vs. 2746.5 thousand in 2016); however, this disparity took a different direction in child and others' care. Women dominated child caregiving with 4.6 times more unworked days than men, while in care for others, the number of days lost among men was 1.7 times higher than days lost among women. The average number of caregiving absence days grew from 0.45 days per worker in 2006 to 0.70 days per worker in 2016. Work absence associated with care provision accounted for $2.7 \%$ of the overall absence in the Polish economy in 2006, and this share increased to $3.7 \%$ in 2016 (Table 1).

The data on the distribution of absence by duration of absence show that the shortest care episodes (lasting 15 days) dominated and were more prevalent in child care than in others' care. The average share of these short episodes for the whole period was $67.9 \%$ of all episodes in child care and $49.7 \%$ of episodes of others' care. On the other hand, episodes lasting 11-14 days were much more common in care of other family members $(30.1 \%$ on average) than of younger children ( $4.4 \%$ on average). In both groups, the share of the shortest episodes (1-5 days) increased notably during the 11-year period investigated; for child care, this proportion increased by 10.9 percentage points (from 62.3 to $73.2 \%$ ), while for others' care, it increased by as much as 16.4 percentage points (from 41.9 to $58.3 \%$ ) (Table 2).

Interestingly, there was a notable gender difference in the structure of care episodes depending on their duration in others' care (similar data for child care were not obtainable). The shortest episodes (1-5 days) were mostly secured by women, who used 92.8 thousand care episodes in 2016, while the corresponding number for men was 50.9 thousand. On the other hand, in the care episodes lasting 6-10 days, 11-14 days and 15+ days, men were those for whom the number of care certificates was higher (Additional file 1). This pattern of gender difference was consistent over time.

The dynamics of absence days varied depending on the caregiver's gender and on whether a child or another person was subject to care. In child care, periods of 2006-2009 and 2015-2016 exhibited a dynamic growth of absence days for caregivers of both genders. For the 
Table 1 Incidence of caregivers' short-term absenteeism in Poland, 2006-2016

\begin{tabular}{|c|c|c|c|c|c|c|c|c|c|c|c|}
\hline & 2006 & 2007 & 2008 & 2009 & 2010 & 2011 & 2012 & 2013 & 2014 & 2015 & 2016 \\
\hline \multicolumn{12}{|l|}{ Child care } \\
\hline Number of absence days (thousand) & 5079.6 & 6165.3 & 6772.1 & 7435.2 & 7169.0 & 7587.3 & 7471.6 & 7934.1 & 7589.8 & 8290.9 & 8938.4 \\
\hline Males & 864.7 & 1046.8 & 1168.9 & 1278.8 & 1273.5 & 1318.0 & 1320.1 & 1465.9 & 1463.2 & 1585.4 & 1746.1 \\
\hline Females & 4116.8 & 5079.8 & 5598.7 & 6155.9 & 5894.8 & 6268.5 & 6149.8 & 6466.1 & 6124.1 & 6702.1 & 7187.7 \\
\hline Average length of absence (days) & 5.58 & 5.58 & 5.52 & 5.43 & 5.36 & 5.29 & 5.22 & 5.06 & 4.91 & 4.90 & 4.84 \\
\hline Absence days per worker & 0.38 & 0.45 & 0.48 & 0.54 & 0.51 & 0.53 & 0.53 & 0.56 & 0.52 & 0.56 & 0.59 \\
\hline Share of total absence days ${ }^{a}$ & $2.3 \%$ & $2.7 \%$ & $2.7 \%$ & $2.8 \%$ & $2.8 \%$ & $3.0 \%$ & $2.9 \%$ & $3.0 \%$ & $2.9 \%$ & $3.0 \%$ & $3.1 \%$ \\
\hline \multicolumn{12}{|l|}{ Others' care } \\
\hline Number of absence days (thousand) & 865.0 & 1017.2 & 1191.5 & 1257.7 & 1265.7 & 1278.4 & 1263.0 & 1293.3 & 1362.1 & 1457.5 & 1675.0 \\
\hline Males & 553.8 & 655.3 & 779.5 & 833.0 & 818.2 & 802.2 & 769.7 & 780.1 & 812.0 & 856.1 & 1000.4 \\
\hline Females & 294.0 & 355.9 & 411.3 & 424.5 & 447.4 & 476.0 & 493.0 & 512.9 & 549.6 & 600.7 & 673.5 \\
\hline Average length of absence (days) & 8.10 & 8.08 & 8.05 & 7.99 & 7.76 & 7.54 & 7.42 & 7.23 & 7.08 & 6.92 & 6.79 \\
\hline Absence days per worker & 0.07 & 0.07 & 0.08 & 0.09 & 0.09 & 0.09 & 0.09 & 0.09 & 0.09 & 0.10 & 0.11 \\
\hline Share of total absence days ${ }^{a}$ & $0.4 \%$ & $0.4 \%$ & $0.5 \%$ & $0.5 \%$ & $0.5 \%$ & $0.5 \%$ & $0.5 \%$ & $0.5 \%$ & $0.5 \%$ & $0.5 \%$ & $0.6 \%$ \\
\hline \multicolumn{12}{|l|}{ Total } \\
\hline Number of absence days (thousand) & 5944.6 & 7182.5 & 7963.6 & 8692.9 & 8434.7 & 8865.7 & 8734.6 & 9227.4 & 8951.9 & 9748.4 & $10,613.4$ \\
\hline Males & 1418.5 & 1702.1 & 1948.4 & 2111.8 & 2091.7 & 2120.2 & 2089.8 & 2246.0 & 2275.2 & 2441.5 & 2746.5 \\
\hline Females & 4410.8 & 5435.7 & 6010.0 & 6580.4 & 6342.2 & 6744.5 & 6642.8 & 6979.0 & 6673.7 & 7302.8 & 7861.2 \\
\hline Absence days per worker & 0.45 & 0.52 & 0.57 & 0.63 & 0.60 & 0.62 & 0.62 & 0.65 & 0.61 & 0.66 & 0.70 \\
\hline Share of total absence days ${ }^{\mathrm{a}}$ & $2.7 \%$ & $3.1 \%$ & $3.2 \%$ & $3.3 \%$ & $3.3 \%$ & $3.5 \%$ & $3.4 \%$ & $3.5 \%$ & $3.4 \%$ & $3.5 \%$ & $3.7 \%$ \\
\hline
\end{tabular}

Notes: a - total absence days refers to the overall number of days associated with own and caregiving absence in Poland

Table 2 Distribution of care episodes by duration of absence in Poland, 2006-2016

\begin{tabular}{|c|c|c|c|c|c|c|c|c|c|c|c|c|}
\hline \multirow[t]{2}{*}{ Duration } & \multicolumn{11}{|c|}{ Number of care episodes in thousands (share in total) } & \multirow{2}{*}{$\begin{array}{l}\text { Average } \\
\text { share } \\
(2006- \\
2016)\end{array}$} \\
\hline & 2006 & 2007 & 2008 & 2009 & 2010 & 2011 & 2012 & 2013 & 2014 & 2015 & 2016 & \\
\hline \multicolumn{13}{|l|}{ Child care } \\
\hline $1-5$ days & $\begin{array}{l}567.0 \\
(62.3 \%)\end{array}$ & $\begin{array}{l}689.9 \\
(62.5 \%)\end{array}$ & $\begin{array}{l}789.2 \\
(64.3 \%)\end{array}$ & $\begin{array}{l}903.9 \\
(66.0 \%)\end{array}$ & $\begin{array}{l}895.4 \\
(66.9 \%)\end{array}$ & $\begin{array}{l}974.9 \\
(67.9 \%)\end{array}$ & $\begin{array}{l}989.7 \\
(69.1 \%)\end{array}$ & $\begin{array}{l}1106.2 \\
(70.5 \%)\end{array}$ & $\begin{array}{l}1112.1 \\
(71.9 \%)\end{array}$ & $\begin{array}{l}1223.0 \\
(72.3 \%)\end{array}$ & $\begin{array}{l}1353.2 \\
(73.2 \%)\end{array}$ & $67.9 \%$ \\
\hline $6-10$ days & $\begin{array}{l}274.0 \\
(30.1 \%)\end{array}$ & $\begin{array}{l}334.0 \\
(30.2 \%)\end{array}$ & $\begin{array}{l}346.3 \\
(28.2 \%)\end{array}$ & $\begin{array}{l}368.5 \\
(26.9 \%)\end{array}$ & $\begin{array}{l}346.0 \\
(25.9 \%)\end{array}$ & $\begin{array}{l}360.2 \\
(25.1 \%)\end{array}$ & $\begin{array}{l}341.0 \\
(23.8 \%)\end{array}$ & $\begin{array}{l}365.0 \\
(23.3 \%)\end{array}$ & $\begin{array}{l}345.5 \\
(22.3 \%)\end{array}$ & $\begin{array}{l}370.9 \\
(21.9 \%)\end{array}$ & $\begin{array}{l}390.1 \\
(21.1 \%)\end{array}$ & $25.4 \%$ \\
\hline 11-14 days & $\begin{array}{l}46.9 \\
(5.2 \%)\end{array}$ & $\begin{array}{l}55.1 \\
(5.0 \%)\end{array}$ & $\begin{array}{l}61.2 \\
(5.0 \%)\end{array}$ & $\begin{array}{l}63.8 \\
(4.7 \%)\end{array}$ & $\begin{array}{l}64.0 \\
(4.8 \%)\end{array}$ & $\begin{array}{l}64.6 \\
(4.5 \%)\end{array}$ & $\begin{array}{l}64.2 \\
(4.5 \%)\end{array}$ & $\begin{array}{l}62.8 \\
(4.0 \%)\end{array}$ & $\begin{array}{l}58.1 \\
(3.8 \%)\end{array}$ & $\begin{array}{l}63.4 \\
(3.7 \%)\end{array}$ & $\begin{array}{l}67.3 \\
(3.6 \%)\end{array}$ & $4.4 \%$ \\
\hline $15+$ days & $\begin{array}{l}21.3 \\
(2.3 \%)\end{array}$ & $\begin{array}{l}25.1 \\
(2.3 \%)\end{array}$ & $\begin{array}{l}30.5 \\
(2.5 \%)\end{array}$ & $\begin{array}{l}32.5 \\
(2.4 \%)\end{array}$ & $\begin{array}{l}32.4 \\
(2.4 \%)\end{array}$ & $\begin{array}{l}35.0 \\
(2.4 \%)\end{array}$ & $\begin{array}{l}35.9 \\
(2.5 \%)\end{array}$ & $\begin{array}{l}34.1 \\
(2.2 \%)\end{array}$ & $\begin{array}{l}29.5 \\
(1.9 \%)\end{array}$ & $\begin{array}{l}33.9 \\
(2.0 \%)\end{array}$ & $\begin{array}{l}36.7 \\
(2.0 \%)\end{array}$ & $2.3 \%$ \\
\hline Unidentified & $\begin{array}{l}0.5 \\
(0.1 \%)\end{array}$ & $\begin{array}{l}0.3 \\
(0.0 \%)\end{array}$ & $\begin{array}{l}0.1 \\
(0.0 \%)\end{array}$ & $\begin{array}{l}0.1 \\
(0.0 \%)\end{array}$ & $\begin{array}{l}0.0 \\
(0.0 \%)\end{array}$ & $\begin{array}{l}0.3 \\
(0.0 \%)\end{array}$ & $\begin{array}{l}0.6 \\
(0.0 \%)\end{array}$ & $\begin{array}{l}0.6 \\
(0.0 \%)\end{array}$ & $\begin{array}{l}0.7 \\
(0.0 \%)\end{array}$ & $\begin{array}{l}0.8 \\
(0.0 \%)\end{array}$ & $\begin{array}{l}1.0 \\
(0.1 \%)\end{array}$ & $0.0 \%$ \\
\hline \multicolumn{13}{|l|}{ Others' care } \\
\hline $1-5$ days & $\begin{array}{l}44.7 \\
(41.9 \%)\end{array}$ & $\begin{array}{l}53.8 \\
(42.7 \%)\end{array}$ & $\begin{array}{l}64.6 \\
(43.7 \%)\end{array}$ & $\begin{array}{l}71.4 \\
(45.3 \%)\end{array}$ & $\begin{array}{l}78.0 \\
(47.8 \%)\end{array}$ & $\begin{array}{l}84.7 \\
(50.0 \%)\end{array}$ & $\begin{array}{l}87.7 \\
(51.5 \%)\end{array}$ & $\begin{array}{l}95.3 \\
(53.3 \%)\end{array}$ & $\begin{array}{l}105.9 \\
(55.1 \%)\end{array}$ & $\begin{array}{l}119.7 \\
(56.8 \%)\end{array}$ & $\begin{array}{l}143.8 \\
(58.3 \%)\end{array}$ & $49.7 \%$ \\
\hline $6-10$ days & $\begin{array}{l}25.3 \\
(23.7 \%)\end{array}$ & $\begin{array}{l}28.4 \\
(22.6 \%)\end{array}$ & $\begin{array}{l}32.1 \\
(21.7 \%)\end{array}$ & $\begin{array}{l}31.5 \\
(20.0 \%)\end{array}$ & $\begin{array}{l}30.2 \\
(18.5 \%)\end{array}$ & $\begin{array}{l}30.3 \\
(17.9 \%)\end{array}$ & $\begin{array}{l}28.7 \\
(16.9 \%)\end{array}$ & $\begin{array}{l}29.5 \\
(16.5 \%)\end{array}$ & $\begin{array}{l}29.7 \\
(15.4 \%)\end{array}$ & $\begin{array}{l}31.1 \\
(14.8 \%)\end{array}$ & $\begin{array}{l}34.6 \\
(14.0 \%)\end{array}$ & $18.4 \%$ \\
\hline $11-14$ days & $\begin{array}{l}34.9 \\
(32.7 \%)\end{array}$ & $\begin{array}{l}41.5 \\
(33.0 \%)\end{array}$ & $\begin{array}{l}48.6 \\
(32.9 \%)\end{array}$ & $\begin{array}{l}51.9 \\
(33.0 \%)\end{array}$ & $\begin{array}{l}52.6 \\
(32.2 \%)\end{array}$ & $\begin{array}{l}51.5 \\
(30.4 \%)\end{array}$ & $\begin{array}{l}50.3 \\
(29.6 \%)\end{array}$ & $\begin{array}{l}50.1 \\
(28.0 \%)\end{array}$ & $\begin{array}{l}52.5 \\
(27.3 \%)\end{array}$ & $\begin{array}{l}55.1 \\
(26.2 \%)\end{array}$ & $\begin{array}{l}62.8 \\
(25.5 \%)\end{array}$ & $30.1 \%$ \\
\hline $15+$ days & $\begin{array}{l}1.8 \\
(1.7 \%)\end{array}$ & $\begin{array}{l}2.2 \\
(1.7 \%)\end{array}$ & $\begin{array}{l}2.6 \\
(1.8 \%)\end{array}$ & $\begin{array}{l}2.7 \\
(1.7 \%)\end{array}$ & $\begin{array}{l}2.4 \\
(1.5 \%)\end{array}$ & $\begin{array}{l}2.9 \\
(1.7 \%)\end{array}$ & $\begin{array}{l}3.4 \\
(2.0 \%)\end{array}$ & $\begin{array}{l}3.8 \\
(2.1 \%)\end{array}$ & $\begin{array}{l}4.1 \\
(2.1 \%)\end{array}$ & $\begin{array}{l}4.6 \\
(2.2 \%)\end{array}$ & $\begin{array}{l}5.2 \\
(2.1 \%)\end{array}$ & $1.9 \%$ \\
\hline Unidentified & $\begin{array}{l}0.0 \\
(0.0 \%)\end{array}$ & $\begin{array}{l}0.0 \\
(0.0 \%)\end{array}$ & $\begin{array}{l}0.0 \\
(0.0 \%)\end{array}$ & $\begin{array}{l}0.0 \\
(0.0 \%)\end{array}$ & $\begin{array}{l}0.0 \\
(0.0 \%)\end{array}$ & $\begin{array}{l}0.1 \\
(0.1 \%)\end{array}$ & $\begin{array}{l}0.1 \\
(0.1 \%)\end{array}$ & $\begin{array}{l}0.1 \\
(0.1 \%)\end{array}$ & $\begin{array}{l}0.1 \\
(0.1 \%)\end{array}$ & $\begin{array}{l}0.1 \\
(0.0 \%)\end{array}$ & $\begin{array}{l}0.1 \\
(0.0 \%)\end{array}$ & $0.0 \%$ \\
\hline
\end{tabular}


years 2010-2014, though women's absence remained fairly stable, men's absenteeism increased perceptibly. On the other hand, in others' care, women's absenteeism increased each year, while in the case of care provided by men, the period of 2010-2012 shows a declining number of unworked days (Fig. 1).

The average duration of child caregiving absence was 5.58 days in 2006 and declined to 4.84 days in 2016. The absence related to adult caregiving lasted longer than that related to child caregiving: 8.10 days in 2006 and 6.79 days in 2016 on average. In both cases, the data show a continuous decline in the duration of absence (Fig. 2).

\section{Indirect costs}

The indirect costs of caregivers' short-term absenteeism in Poland were €306.2 million in 2006, and they increased to $€ 824.1$ million in 2016. To account for economic growth, the costs were expressed as a share of GDP; the productivity losses due to care provision accounted for $0.116 \%$ of GDP in 2006, and this share increased to $0.180 \%$ in 2016 , more than a $50 \%$ rise. The total cost grew year by year, apart from 2010 and 2014 (in nominal values) and 2012 (in GDP-related terms). Care provided to children up to 14 years of age generated $84.2-86.0 \%$ of the total costs depending on year, while the remaining $14.0-15.8 \%$ resulted from care to other family members. The cost per episode of care was $€ 301.3$ in 2006 and increased to €393.4 in 2016, and it was considerably lower for child care $(€ 287.6-€ 375.5)$ than for others' care $(€ 417.6-€ 527.6)$. The productivity losses due to informal caregiving translated to a country's labour market level as a cost of $€ 23.3$ per worker in 2006 and $€ 54.3$ per worker in 2016 (Table 3).

\section{Sensitivity analysis}

Table 4 reports the results of a one-way sensitivity analysis of indirect costs associated with informal caregiving in Poland; for the sake of brevity, the analysis was only conducted for the year 2016. Using extreme values of

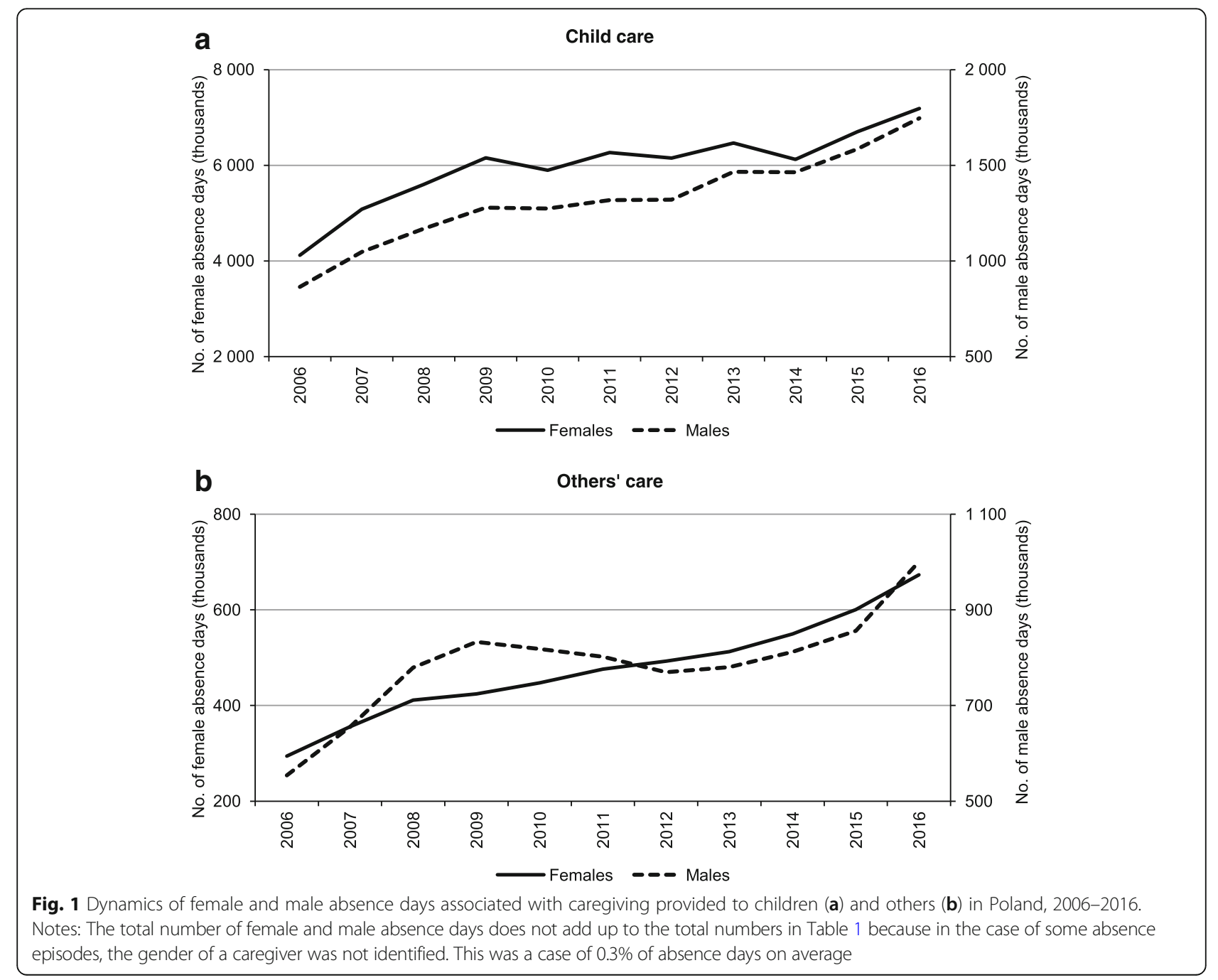




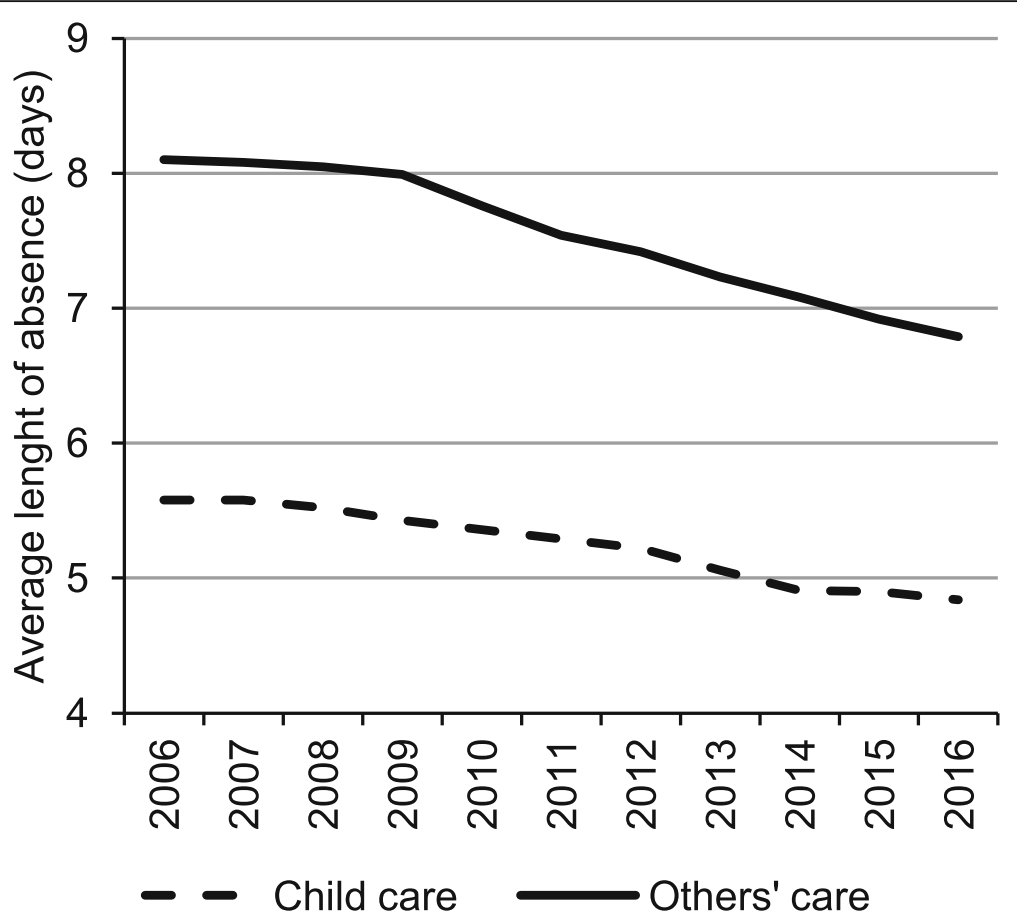

Fig. 2 Average length of absence associated with caregiving provided to children and others in Poland, 2006-2016

exchange rate from the whole period varied the estimates from -6.8 to $+15.8 \%$. Varying the value of the coefficient adjusting for decreasing labour productivity by \pm 0.05 and accounting for potential lower caregivers' productivity resulted in changes in productivity losses ranging from -30.8 to $+7.7 \%$. When gross value added was used as a productivity measure, the costs were $11.5 \%$ lower than in the base scenario. Accounting for part-time employment decreased indirect costs by $3.1 \%$ (Table 4 ).

\section{Discussion}

This is the first study to use social insurance data to assess the indirect costs associated with informal caregivers' short-term absenteeism in Poland. Using the HCM and the societal perspective, the study estimated the economic burden of short-term caregiving in Poland for the 11-year period (2006-2016). The results show that the productivity losses attributable to the provision of short-term care were $€ 306.2$ million in 2006 and more than doubled, reaching €824.1 million in 2016. This increase was much higher than of the increase in GDP; the dynamics of the economy's output grew by $74 \%$ in the period investigated, while the indirect costs of absence associated with care increased by $169 \%$. This cost escalation reflects a growing number of caregivers' absence days throughout the period and was not outweighed by the diminishing duration of the average absence episode.

Notably, the dynamic increase in caregiving incidence and costs observed in Poland cannot be explained by epidemiological patterns or demographic situation as no dramatic changes that could increase absence were observed in these areas. Consider the demography trends of the two groups with potentially the greatest care needs, namely, the young and the elderly populations: although the share of the population aged $65+$ years increased by $3 \%$ in the period investigated, this rise was accompanied by a drop of similar magnitude $(-2.6 \%)$ in the population aged $0-18$ years (see Additional file 2 for details). Considering that it was the youngest population that generated the vast majority of the short-term absence, it seems that the overall demographic factors in these two groups do not explain the nearly two-fold increase in the number of absence days. Thus, it is possible that factors other than health or demography may influence the frequency of caregiving; social insurance arrangements or labour market situations could potentially play a role. Of these two, the former remained fairly stable across the period; on the other hand, the labour market situation improved notably, with the unemployment rate dropping from $18 \%$ in 2006 to $8.2 \%$ in 2016. A more favourable labour market situation for employees could have resulted in a greater inclination to use care allowances because workers were less afraid of job loss. This mechanism has not been investigated in the area of caregivers' absenteeism; however, previous studies on own absence suggest such a relationship [37-39].

Few studies have estimated the indirect costs of informal caregiving, and none of them have used a methodological approach similar to the one adopted here, which 


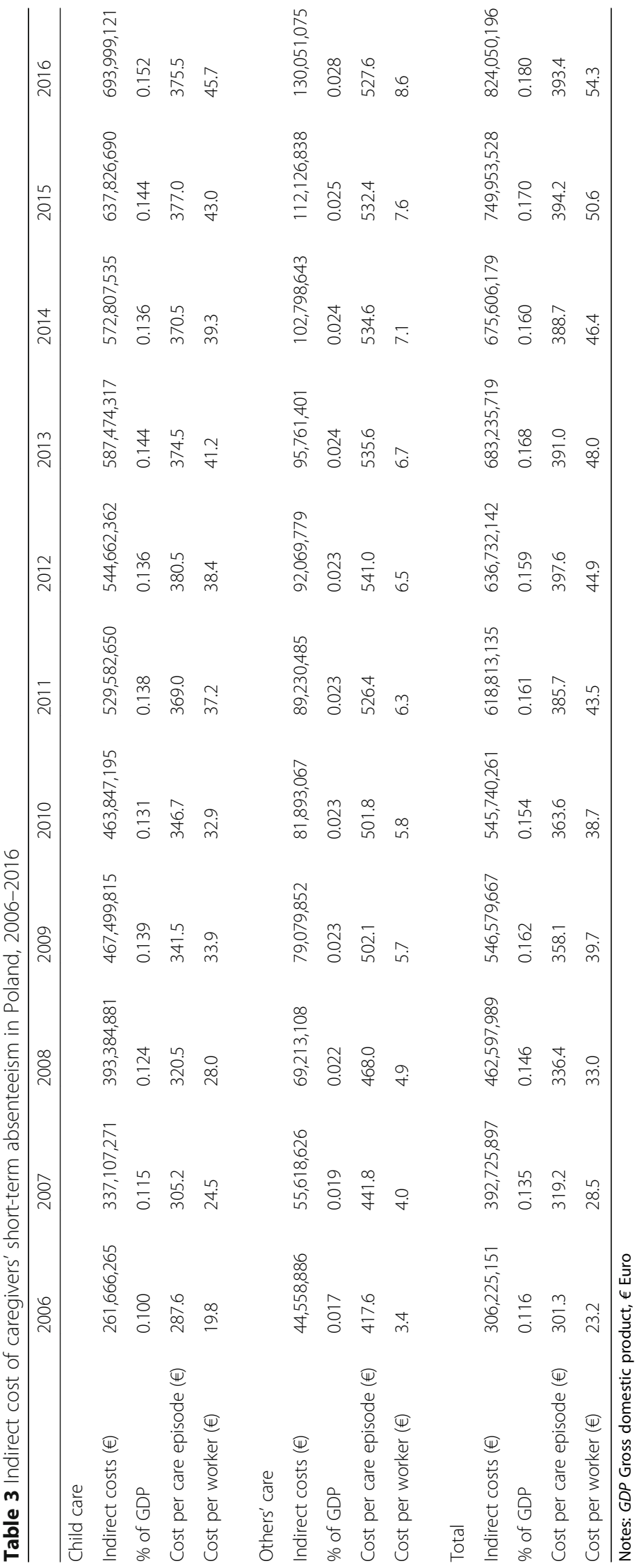


Table 4 Sensitivity analysis for indirect cost of cost of caregivers' short-term absenteeism in Poland (2016) according to varied assumptions for model parameters

\begin{tabular}{lll}
\hline & Indirect cost (€) & $\begin{array}{c}\text { Change from } \\
\text { base scenario }\end{array}$ \\
\hline Base scenario (BS) & $824,050,196$ & - \\
Exchange rate (BS: 4.07) & & $15.8 \%$ \\
3.51 & $954,311,539$ & $-6.8 \%$ \\
4.36 & $768,247,360$ & \\
Coefficient to adjust for decreasing marginal & & $-30.8 \%$ \\
labour productivity (BS: 0.65$)$ & $570,496,289$ & $7.7 \%$ \\
$\quad 0.45$ & $887,438,672$ & $-11.5 \%$ \\
$\quad 0.70$ & & $-3.1 \%$ \\
Productivity measure (BS: gross domestic product) & $729,355,474$ & $798,504,639$ \\
$\quad$ Gross value added & & \\
Part-time employment adjustment & & \\
\hline
\end{tabular}

accounts for unworked days based on insurance data and is not based on potential economic losses or replacement costs. The American study from 2006 reports that the cost of absenteeism for employers was $\$ 7.0$ billion, which translated to an equivalent of $\$ 441$ per employed caregiver [40]; however, according to a recent review, these estimates should be treated with caution because the study makes debatable assumptions in carrying out the analysis [14]. The other research based on 2010 data estimates the cost of caregivers' absenteeism for the US economy at $\$ 25.2$ billion [18], or $0.168 \%$ of the country's GDP. On the other hand, the opportunity costs of informal care for elderly Americans in the period 2011-12 amounted to $\$ 522$ billion annually, while the cost of replacing this care varied from $\$ 221$ billion to $\$ 642$ billion depending on whether the care would be delivered by unskilled or skilled workers [41]. A recent Australian study estimates the replacement cost of informal caregiving in 2015 at $\$ 60.3$ billion, equivalent to $3.8 \%$ of GDP [19].

This variation in the estimates of caregiving costs shows that comparability of results from a range of studies is limited because the estimates critically depend on the studies' settings. The inclusion of such categories as employees' replacement costs, workday interruptions or unpaid leave in some studies elevates costs compared to the cost reported in studies assessing the impact of absenteeism alone. Moreover, relying on administrative data, as in this study, restricts analysis to the productivity losses associated with absence from formal work and does not allow the inclusion of cost categories that are not routinely reported for formal purposes, such as presenteeism or the value of housekeeping services undone. Additionally, the way productivity losses are valued (opportunity costs vs. market wages or per worker productivity) affects the estimates. For these reasons, the estimates from the present study are hardly comparable with others' findings. However, the results of the American study, which estimates the costs of absenteeism at $\$ 25.2$ billion [18], are of similar magnitude in GDP-related terms $(0.168 \%$ of US's GDP in 2010$)$ to estimates from this study ( $0.154 \%$ of Polish GDP in the same year).

The results of the present study emphasize complex gender-related disparities in informal care provision. Overall, women lost approximately three times more work days to caregiving than did men. However, this difference was mainly due to the disparity in caring for younger children, while men dominated care for others (adults and older children). The higher incidence of child care among women possibly reflects both an earnings gap between men and women and differences in the distribution of traditional societal roles associated with gender. Because in Poland absence associated with caregiving is subject to a $20 \%$ reduction in the employee's earnings, the economic loss for a family caring for a child is lower when the parent receiving the lower salary provides care. Women in Poland receive $7.2 \%$ lower gross hourly earnings than men do (data for 2016) [42] and, for this reason, the cost of care for a household is on average lower when the woman provides care. Additionally, the distribution of traditional social roles attributes more care responsibilities to women [43], and this probably strengthens the gender-related earnings gap effect. On the other hand, though men are those who provide more care days to other family members, a closer inspection of this category shows a more complicated gender-related pattern of caregiving. Short care episodes (1-5 days) are mostly secured by women, while in long-lasting episodes (6 or more days), men dominate caregiving, as shown in the above results (see Additional file 1 for details). It is possible that short episodes are more often those involving older children (aged >14) in 
which case women are more likely to deliver care due to the reasons explained above. On the other hand, men's dominant role in longer care episodes perhaps reflects higher female morbidity and the fact that, in most cases, the only person able to provide care for a sick woman is her husband. In this case, there is usually no choice regarding the person who provides care, and because women are more frequently sick, informal care is provided by their male spouses.

\section{Limitations of the study}

This study has the following limitations. Firstly, the estimates only provide evidence on the productivity losses associated with absences that were registered in the social insurance system. Thus, unrecorded care episodes (e.g. provided by those using holiday instead of formal absence) are not included and this fact underestimates the real burden. Secondly, the present study does not show the overall indirect costs of caregiving in Poland; it is limited to short-term absenteeism only, and the burden of long-term or permanent caregiving translating to economic inactivity is not investigated here. Thirdly, economic losses due to housekeeping activities undone and to presenteeism of caregivers are not included because of data unavailability, and this also biases the results downwards. Finally, these estimates do not allow the identification of the costs attributable to particular diseases; the SII does not collect data on diagnoses for caregivers' absenteeism as it does in own sickness absenteeism, where ICD-10 codes are attributed to each absence episode.

\section{Conclusions}

In conclusion, this study estimates the indirect costs of informal caregivers' short-term absenteeism in Poland for the period from 2006 to 2016. Using the data on caregiving incidence from the social insurance system it has been shown that the costs of productivity losses associated with care provision for family members increased from $€ 306.2$ million in 2006 to $€ 824.1$ million in 2016. The study shows that both the incidence and the costs of caregiving in Poland are growing rapidly, and their dynamics exceed the growth rates of the economy and the dynamics of own sickness absence. The study also confirms the dominant role of women in short-term caregiving, which has been confirmed previously in several studies concerned with long-term care.

\section{Endnotes}

${ }^{1}$ To the best of the author's knowledge, estimates of productivity decrease in the general population of caregivers in short-time absence are not available. Although a growing body of disease-specific evidence exists (e.g., for advanced cancer [34] or post-stroke spasticity [35]), the applicability of these estimates in the context of short-term absenteeism is questionable. Therefore, the arbitrary change of -0.15 was used

\section{Additional files}

Additional file 1: Distribution of care episodes by duration of absence and gender of caregiver in others' care in Poland, 2006-2016. (PDF 97 kb)

Additional file 2: Change in selected population age structure measures during the period of the study in Poland. (PDF $95 \mathrm{~kb}$ )

\section{Abbreviations}

BS: Base scenario; GDP: Gross domestic product; HCM: Human capital method; SII: Social Insurance Institution; US: United States

\section{Acknowledgements}

The author thanks Agnieszka Matysiak for her language assistance and Ewa Karczewicz from Social Insurance Institution for providing additional data. He also thanks Stefan Auener and Jacqualine Anne Robinson who reviewed the paper and provided valuable input on earlier versions of the manuscript.

\section{Funding}

No funding was received for this research

\section{Availability of data and materials}

All the data used were retrieved from the publicly available sources provided in the references or obtained from Social Insurance Institution on request.

\section{Authors' contributions}

The author read and approved the final manuscript.

\section{Authors' information}

Błażej Łyszczarz holds a PhD in Economics and is currently Assistant Professor in the Department of Public Health, Faculty of Health Sciences, Nicolaus Copernicus University in Toruń, Poland. He is also a member of the Scientific Council at the Institute of Innovation and Responsible Development INNOWO.

Ethics approval and consent to participate

The study did not involve any human participants; it relied solely on data collected for other purposes. Because this study was not an experiment, ethics approval was not sought.

Consent for publication

Not applicable.

\section{Competing interests}

The author declares that he has no competing interests.

\section{Publisher's Note}

Springer Nature remains neutral with regard to jurisdictional claims in published maps and institutional affiliations.

Received: 16 October 2018 Accepted: 8 May 2019

Published online: 17 May 2019

\section{References}

1. Yuda M, Lee J. Effects of informal caregivers' health on care recipient. Jpn Econ Rev. 2016;67:192-210

2. Kelley DE, Lewis MA, Southwell BG. Perceived support from a caregiver's social ties predicts subsequent care-recipient health. Prev Med Rep. 2017:8:108-11.

3. Vitaliano PP, Zhang J, Scanlan JM. Is caregiving hazardous to one's physical health? A meta-analysis. Psychol Bull. 2003;129:946-72.

4. Brown RM, Brown SL. Informal caregiving: a reappraisal of effects on caregivers. Soc Issues Policy Rev. 2014;8:74-102.

5. Wolff J, Spillman B, Freedman V, Kasper J. A national profile of family and unpaid caregivers who assist older adults with health care activities. JAMA Intern Med. 2016;176:372-9. 
6. Hanly P, Céilleachair AO, Skally M, O'Leary E, Kapur K, Fitzpatrick P, Staines A. How much does it cost to care for survivors of colorectal cancer? Caregiver's time, travel and out-of-pocket costs. Support Care Cancer. 2013; 21:2583-92.

7. Oliva-Moreno J, Trapero-Bertran M, Peña-Longobardo LM, del Pozo-Rubio R. The valuation of informal care in cost-of-illness studies: a systematic review. PharmacoEconomics. 2017:35:331-45.

8. Albrecht D, Wollensak T, Ernst C, Becker C, Hautzinger M, Pfeiffer K. Costs of informal care in a sample of German geriatric stroke survivors. Eur J Ageing. 2016:13:49-61.

9. Keating NC, Fast JE, Lero DS, Lucas SJ, Eales J. A taxonomy of the economic costs of family care to adults. J Econ Aging. 2014;3:11-20.

10. Tranmer JE, Guerriere DN, Ungar WJ, Coyte PC. Valuing patient and caregiver time. PharmacoEconomics. 2005;23:449-59.

11. Carmeli $E$. The invisibles: unpaid caregivers of the elderly. Front Public Health. 2014;2:91.

12. van den Berg B, Brouwer WBF, Koopmanschap MA. Economic valuation of informal care: an overview of methods and applications. Eur J Health Econ. 2004;51:36-45.

13. Koopmanschap MA, van Exel JNA, van den Berg B, Brouwer WBF. An overview of methods and applications to value informal care in economic evaluations of healthcare. Pharmacoeconomics. 2008;26:269-80.

14. Committee on Family Caregiving for Older Adults; Board on Health Care Services; Health and Medicine Division; National Academies of Sciences, Engineering, and medicine. In: Schulz R, Eden J, editors. Families caring for an aging America. Washington DC: National Academies Press; 2016.

15. Rosenman R, Tennekoon V, Hill LG. Measuring bias in self-reported data. Int J Behav Healthcare Res. 2011;2:320-32.

16. Akobundu $E$, Ju J, Blatt L, Mullins CD. Cost-of-illness studies: a review of current methods. Pharmacoeconomics. 2006;24:869-90.

17. Arno PS, Levine C, Memmott MM. The economic value of informal caregiving. Health Affairs (Millwood). 1999;18:182-8.

18. Gallup-Healthways. Gallup-Healthways well-being survey: caregiving costs $U$. S. economy $\$ 25.2$ billion in lost productivity. 2011. https://news.gallup.com/ poll/148670/caregiving-costs-economy-billion-lost-productivity.aspx. Accessed 21 Feb 2019.

19. Carers Australia. The economic value of informal care in Australia in 2015. Canberra: Deloitte Access Economics; 2015.

20. Dwyer RE. The care economy? Gender, economic restructuring and job polarization in the US labor market. Am Sociol Rev. 2013;78:390-416.

21. Yenilmez Ml. Economic and social consequences of population aging the dilemmas and opportunities in the twenty-first century. Appl Res Qual Life. 2015;10:735-52.

22. Knickman JR, Snell EK. The 2030 problem: caring for aging baby boomers. Health Serv Res. 2002;37:849-84.

23. Gudnadottir G, Tennvall GR, Stalfors J, Hellgren J. Indirect costs related to caregivers' absence from work after paediatric tonsil surgery. Eur Arch Otorhinolaryngol. 2017:274:2629-36.

24. Ortega-Sanchez IR, Molinari NA, Fairbrother G, Szilagyi PG, Edwards KM, Griffin MR, Cassedy A, Poehling KA, Bridges C, Staat MA. Indirect, out-ofpocket and medical costs from influenza-related illness in young children. Vaccine. 2012;30:4175-81.

25. Pagano E, Baldi I, Mosso ML, di Montezemolo LC, Fagioli F, Pastore G, Merletti $F$. The economic burden of caregiving on families of children and adolescents with cancer: a population-based assessment. Pediatr Blood Cancer. 2014;61:1088-93.

26. de Muizon MJ. Why do married women work less in the UK than in France? Labour Econ. 2018:51:86-96.

27. Gordon RA, Kaestner R, Korenman S. Child care and work absence: tradeoffs by type of care. J Marriage Fam. 2008;70:239-54.

28. ZUS. Informacja do wniosku o zasiłek opiekuńczy [Information on the application for care allowance], http://www.zus.pl/wzory-formularzy/zasilki/ zasilek-opiekunczy/-/publisher/details/1/wniosek-z-15b/1111160. Accessed 21 Feb 2019.

29. ZUS. Absencja chorobowa w 2016 roku [Sickness absence in 2016]. Warsaw: ZUS; 2017. (also: editions from 2006-2015 years)

30. Oliva J, Lobo F, Lopez-Bastida J, Zozaya N, Romay R. Indirect costs of cervical and breast cancers in Spain. Eur J Health Econ. 2005;6:309-13.

31. Krol M, Brouwer W, Rutten F. Productivity costs in economic evaluations: past, present, future. PharmacoEconomics. 2013;31:537-49.
32. Havik K, Mc Morrow K, Orlandi F, Planas C, Raciborski R, Röger W, Rossi A, Thum-Thysen A, Vandermeulen $\mathrm{V}$. The production function methodology for calculating potential growth rates \& output gaps. Economic papers 535. Brussels: European Commission; 2014.

33. EY. Metodyka pomiaru kosztów pośrednich w polskim systemie ochrony zdrowia [methodology of estimating indirect costs in polish health care system]. Warsaw: EY; 2013.

34. Mazanec SR, Daly BJ, Douglas SL, Lipson AR. Work productivity and health of informal caregivers of persons with advanced cancer. Res Nurs Health. 2011;34:483-95.

35. Ganapathy V, Graham GD, DiBonaventura MD, Gillard PJ, Goren A, Zorowitz RD. Caregiver burden, productivity loss, and indirect costs associated with caring for patients with poststroke spasticity. Clin Interv Aging. 2015;10:1793-802.

36. Eurostat. Part-time employment rate. https://ec.europa.eu/eurostat/tgm/ table.do?tab=table\&init $=1 \&$ language $=$ en \&pcode $=$ tesem $100 \&$ plugin $=1$. Accessed 21 Feb 2019.

37. Shoss MK, Penney LM. The economy and absenteeism: a macro-level study. J Appl Psychol. 2012;97:881-9.

38. Virtanen M, Kivimäki M, Elovainio M, Virtanen P, Vahtera J. Local economy and sickness absence: prospective cohort study. J Epidemiol Community Health. 2005;59:973-8

39. Audas R, Goddard J. Absenteeism, seasonality, and the business cycle. J Econ Bus. 2001;53:405-19.

40. Wagner $\mathrm{DL}$, Lottes J, Neal M. The MetLife caregiving cost study: productivity losses to US business. Westport: MetLife Mature Market Institute; 2006.

41. Chari AV, Engberg J, Ray KN, Mehrotra A. The opportunity costs of informal elder-care in the United States: new estimates from the American time use survey. Health Serv Res. 2015;50:871-82.

42. Eurostat. Gender pay gap statistics. http://ec.europa.eu/eurostat/statisticsexplained/index.php/Gender_pay_gap_statistics\#Gender_pay_gap_levels_ vary_significantly_across_EU. Accessed 21 Feb 2019.

43. Bauer JM, Sousa-Poza A. Impacts of informal caregiving on caregiver employment, health, and family. J Popul Aging. 2015:8:113-45.

\section{Ready to submit your research? Choose BMC and benefit from:}

- fast, convenient online submission

- thorough peer review by experienced researchers in your field

- rapid publication on acceptance

- support for research data, including large and complex data types

- gold Open Access which fosters wider collaboration and increased citations

- maximum visibility for your research: over $100 \mathrm{M}$ website views per year

At $\mathrm{BMC}$, research is always in progress.

Learn more biomedcentral.com/submissions 